Document downloaded from:

http://hdl.handle.net/10251/43602

This paper must be cited as:

Serra Lluch, J.; García Codoñer, A.; Torres Barchino, AM.; Llopis Verdú, J. (2012). Color Composition Features in Modern Architecture. Color Research and Application. 37(2):126133. doi:10.1002/col.20657.

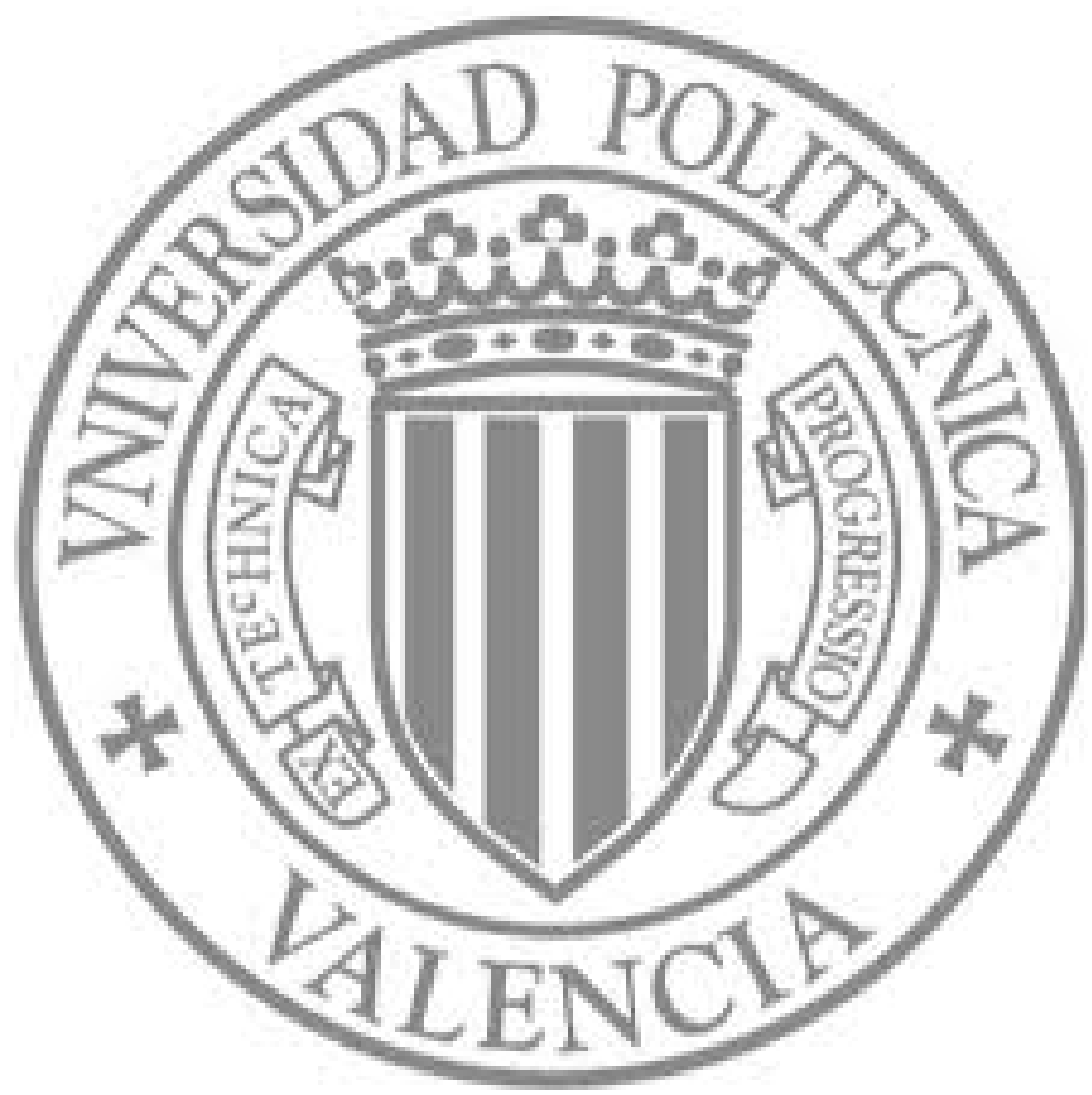

The final publication is available at

http://dx.doi.org/10.1002/col.20657

Copyright Wiley 


\section{COLOR COMPOSITION FEATURES IN MODERN ARCHITECTURE}

\begin{tabular}{|r|l|}
\hline Journal: & Color Research and Application \\
\hline Manuscript ID: & Draft \\
\hline Wiley - Manuscript type: & Research Article \\
\hline Date Submitted by the \\
Author: & $\mathrm{n} / \mathrm{a}$ \\
\hline Complete List of Authors: & $\begin{array}{l}\text { Serra, Juan; Escuela Técnica Superior de Arquitectura, Expresión } \\
\text { Gráfica Arquitectónica } \\
\text { Garcia-Codoñer, Angela; Universidad Politécnica de Valencia, } \\
\text { Departamento de Expresión Gráfica Arquitectónica } \\
\text { Torres, Ana; Universidad Politécnica de Valencia, Departamento de } \\
\text { Expresión Gráfica Arquitectónica } \\
\text { Llopis, Jorge; Universidad Politécnica de Valencia, Departamento de } \\
\text { Expresión Gráfica Arquitectónica }\end{array}$ \\
\hline Keywords: & \begin{tabular}{l} 
Architecture, Color Theory, Color Composition, Modern Architecture \\
\hline
\end{tabular} \\
\hline
\end{tabular}

\section{๑) ScholaroNE" \\ Manuscript Central}

THIS IS THE PRE-PEER REVIEWED VERSION OF THE FOLLOWING ARTICLE:

"Color composition features in modern architecture", COLOR RESEARCH \& APPLICATION

Volume 37, Issue 2, April 2012, Pages: 126-133, Juan Serra, Ángela García, Ana Torres and Jorge Llopis

Article first published online : 1 MAR 2011, DOI: 10.1002/col.20657

Which has been published in final format at:

http://onlinelibrary.wiley.com/doi/10.1002/col.20657/abstract 


\footnotetext{
* Chronological Bibliography on Color Theory. http://www. fadu.uba.ar/sicyt/color/bib.htm. Last updated: August 1, 200. Compiled by José Luis Caivano with the assistance of Paulina Becerra. Collaborators: Juliana Agostinelli, Rodrigo Amuchástegui, Gracia Cutuli, Mario Chegaray, Julieta Garavaglia, Mabel López, Cristina Manganiello, María Luisa Musso, Manuel Net, Andrea Pappier, Pablo Valle.
}

\section{Short summary}

The color composition in modern architecture has been often characterized in a simplistic manner. In fact, this is a complex phenomenon to be studied because of the disparity of proposals and the uniqueness of the architects involved. This research strats with a comparative study of three of the most relevant color composition systems in the first half of the $20^{\text {th }}$ century (Purism and Le Corbusier, Expressionism and B. Taut, Neoplasticism and TG Rietveld), and aims to find common characteristics between them, discussing the validity of some widespread ideas about it, such as the prominence of white hues, the use of "flat colors", or the conception of color during the ideation phase.

We propose and demonstrate three principles that are not categorical about the color composition in modern architecture: it limits the variety of hues, but not only uses white color; it displays color to conform shapes, but also to transform them; and color has ethical connotations and not only aesthetic ones.

\section{Objetives}

This research aims to find common characteristics between different chromatic compositional systems in modern architecture, discussing the validity of some widespread ideas about it, such as the prominence of white hues, the use of "flat colors", or the conception of colour during the ideation phase.

The aim is to contextualize in an approximate manner, never exclusive, the main contributions of the avant-gardes in relation to architectural color composition, taking into account the very personal aspect of each proposal, both by the uniqueness of the colored building as well as its author.

\section{Methodology}

The analytical method includes the following tasks:

1. Collection of data and relevant information to the study:

1.1. Literature review of the information contained in some of the main databases and repositories, with special reference to the "Chronological Bibliography on Color Theory" " held by Professor JL Caivano.

1.2. Visit and documentation of some of the most important modern colored buildings in the European context. 
1.3. Meetings with specialists and architects involved in research on color and architecture in different international forums (SEDO color congressess, AIC congresses, etc..) and color research centers (Istituto del Colore Politecnico de Milano, Grupo de Investigação de Cor da Universidade Lisboa Lusiada, Colour Laboratory at Oxford Brookes University). Interviews with prestigious architects dealing with color ${ }^{1}$, etc.

2. Analysis and structure of the information:

2.1. Selection of architects to study and their main colored buildings: Le Corbusier, B. Taut and G.T. Rietveld.

2.2. Design of an analytical chart that systematizes the analysis of the chromatic composition of their buildings, with the following information: identification of the building, physical description of every relevant color aspect, artistic context, visual strategies, intentions and bibliography.

2.3. Design of a conceptual order that unifies the intentions expressed by the architects in relations with their color arrangements.

3. Interpretation and critical discussion of the results, assessing the validity of some concepts commonly linked with modern color.

\section{The Modern Movement or the International Style.}

In 1932, Philip Johnson (1906) and Henry Russell-Hitchcock (1903-1987) published the book of the exhibition at the Museum of Modern Art (MoMA) in New York titled "The International Style: Architecture since 1922", and set the canonical bases of an architectural style that did not exist in a conscious manner and in which it converges the work of European and American architects with different concerns.

Johnson and Hitchcock, drawing on the Heinrich Wölfflin's iconological critic (1864-1945), focused on the description of the appearance and the language of European modernism rather than on its utopian and social ideological background. They stressed three principles to characterize the new modern architecture: its conception as a volume rather than a mass; the principle of regularity rather than the axial symmetry, and the absence of decoration ${ }^{2}$. Formal aspects such as the "free ground", oblong windows, flat roofs, lack of ornaments, or the use of steel, concrete and glass as a coating, come to be the inexorable stylistic features for every building claimed to be "modern" ${ }^{3}$.

In regard to the color, Johnson and Hitchcock show that, in an initial period of modern movement, 'white stucco was omnipresent', but at a late-stage they identify the three trends selected in our study: 'Both in the Netherlands [Neoplasticism] as in Germany [Expressionism], small areas of primary colors were used; while in France [Purism], large areas of a more neutral color. Both color displays were largely due to the influence of two different trends of abstract painting: first, the one represented by Mondrian and, secondly, the one defended by Ozenfant'. They recognize, nevertheless, that 'most of the walls were still white' 2 .

In relation to color, architectural modernity was finally identified with some compositional aspects such as the prominence of white color, the use of "flat colors" or homogeneous colors (with no changes in hue, value or chroma all along its surface) or the need to integrate the color concepts from the very early stages of the building 


\section{Fewer shades, but not only white}

The false belief that modern architecture only used the white color has finally become almost a mythic conception ${ }^{9}$, which has been denounced by numerous critics. Le Corbusier's buildings 'were never white, anyway all' ${ }^{10}$. The Ville Saboie (Paris, 1929-1931) is certainly a paradigmatic example, as in the collective imaginary it is remembered as a white icon of modernity, but both its inner spaces and the roof were colorfully. In fact, Le Corbusier painted in dark green the whole ground floor of the villa to camouflage with the background forest. A color composition that "disguises" in order to emphasize the purism of the upper white prism supported on pilotis.

If we consider that the MoMA exhibition showed a model of the Ville Saboie and the caption in the catalog emphasizes the use of pink and blue on the roof, we have to agree with Mark Whigley noting that the only possible explanation for the triumph of modernity is a sort blindness, and the consequence is that color "separates from the main narrative of architecture" " 8 . This blindness is fuelled both by the Loosian (18701933) hostility to decor and the Ruskinian (1819-1900) defense of "material truth", and historians of the modern movement contributed to it, as they presented the avant-garde architects as "mythical heroes that faced up to academic decadence and legitimized the values of a new morality with educational, regenerative and hygienists consequences" 11. There are some other deep cultural reasons to understand what some critics have identified as a genuine "chromophobia" in Western thought, with such significant masters like Aristotle, Plato or Goethe ${ }^{12}$.

Although modern architecture was not only in white color, there is a conscious limitation of the color range by some of the most important architects who dealt with

\footnotetext{
† Peter Eisenman (1932-), Michael Graves (1934-), Charles Gwathmey (1938-), John Hedjuk (1929-2000) y Richard Meier (1934-)
} 
color. Both Le Corbusier, Taut and Rietveld, state differences between their job as architects and painters, and distinguish appropriate tonal ranges for each field.

In his initial texts ${ }^{\ddagger}$, Le Corbusier warns against the danger of color rather to encourage architects to use it. The Swiss master does not want the 'wall to become a tapestry, and the architect a upholsterer' and he aims to 'reject the colors that can be qualified as non-architectural, better than that, make a research and choose those colors that can eminently be called architectural, and restrict to them, and say to ourselves: It's enough with these!" ${ }^{13}$. And that is the way he does, selecting a narrow range of earthy shades, which he sets in the wallpaper color charts for Salubra (1931).

The German architect Bruno Taut, like Le Corbusier, differentiates himself between being a painter and an architect, giving priority to later one: "The painter I have in me is subordinated to the architect. For me, painting can never be a main aim". $\mathrm{He}$ also agrees with considering that there are hues suitable for architecture and others corresponding to painting. In general, Taut rejects the secondary colors (orange, violet and green) because they are considered too shoking for architecture and better chooses pure colors with different brightness, depending on the characteristics of the spaces: "First of all, it must prevail the maximum purity of the color composition as a main objective, so this purity of color and light has to be consistent with the purity of the rest of the building components, that is, space, mass and style" ${ }^{15}$.

Taut also warns of the danger of multicoloured provisions: "The pure and bright colors are wonderful, but wrong applied, they are much worse than the absence of color. (...) Bright colors together are not yet any color, in the same way that loud sounds all together don't compound a melody" ${ }^{16}$. But do not be misled; the German architect is a strong advocate of bold color compositions, especially in urban areas, where he ensures that "half- measures" are not advisable. Taut's color "purity" does not oppose a great creative freedom, and certainly it is far long from Le Corbusier's rigid purism and neoplasticists's narrow range of hues.

Indeed, neoplastic chromatic system stands out for using only the subtractive basic colors (red, yellow and blue) and those neutral (white, black and gray). Some critics link this "essential" color provisions to the notion of "primitivism" that encouraged other contemporary architects to display white shades ${ }^{17}$.

With regard to the dialectic architecture-painting, neoplasticists claim for a symbiosis between both disciplines and position in favor of none. Both need and complement each other as "the painting detached from architecture (canvas) no longer has any right to exist" ${ }^{18}$. Dutch painter Bart van der Leck (1876-1958) states: "If architects look for a painter who can find the desired image, not least the modern painter looks for an architect who can provide appropriate conditions for a real perfect union of visual plastic expression $" 19$.

\section{Colors conform, but also transform}

Color in modern architecture is provided in a consistent manner with the composition of form and space, so we can say that it "conforms". Thus, Le Corbusier displays colour in buildings to strengthen and emphasize the geometry of the volumes ${ }^{20}$. However, Le Corbusier also used color to introduce tension into the "spatial box" and transform inner spaces. To achieve what Fernand Léger (1881-1955) called the "elastic rectangle" ${ }^{21}$. Rietveld goes further in the transformation and provides color to stress the

\footnotetext{
† Apres Le Cubisme (1918) y Purisme (1921)
} 
break of the volume and the visual independence of each of the elements that compose his famous Schröeder House (Utrecht, 1924). The different planes are independent both physically and visually through color, which accentuates and settles the identity of every singular element. In this sense, the color not only conforms but also transforms, showing the spread of the architectural parts.

In any case, it is a color provision intrinsically linked with the conception of the building form, deeply consistent with it, and distant from classical color provisions understood in a decorative superfluous manner, added a posteriori. In 1901, the German architect Fritz Schumacher (1869-1947) states that "it is difficult to introduce color in a building which has not been designed in color, even choosing the materials or the shades afterwards. Any aesthetic potential in a building should be supported by color from the beginning" ${ }^{14 \mathrm{~b}}$. We note, however, that modern architects not always think on color during the designing process, but a posteriori.

It happens with some of the chromatic provisions in urban space that B. Taut oversees when he is a building town councillor in Magdeburg. These color compositions on pre-existing facades often transform the visual understanding of shapes in relation to their classical composition.

We know at least two cases in which Le Corbusier provides colors (thinks on color) once the building is finished: the Unité d'Habitation (Marseille, 1947) and Les quartiers modernes Fruges (Pessac, 1924-1926).

As the architect himself argues, the fact that the jambs and lintels of the concrete brisoleil of the Unité are polychrome is very reluctantly and color is displayed to mitigate execution errors during the building: "In the very turmoil of construction, there was not a waste, or an annoying wall, or a lack (...), [except for] a stained-glass window out of regular proportion and some concrete blocks formed in inappropriate casts (...) That rebellion of numbers against the harmonics of Modulor was so distressing for me that arose, at the height of exasperation, the invention of exterior polychromy of the Unité. (...) Without those mistakes, Marseille unit would never have been painted outside" 22 .

In Pessac, Le Corbusier provides colors on the facades of a residential complex that, once built, seemed too compact. The color was used "to distance each house, every one in relation to the following, so the perspectives are open, to break the squeeze of the walls (...). Thanks to color, we create an optical illusion, and within, different perception of those elements" ${ }^{13}$. Together with these dimensional reasons, architect adds a simple vital need, as the gray cement plaster had an "unbearable sadness", which "involved the use color to give interest". The arrangement of these colors could be motivated by Mr. Frugés himself: " Le Corbusier's buildings in Pessac did not success, running out of potential inhabitants, who found them dull: these cubes all identical, grouped in the middle of nature, unrelated to the traditional architecture of Bordeaux or the style of the surrounding rural residences; hence the idea of the architect (or perhaps his client Henry Frugés) to paint them" ${ }^{23}$.

It should not surprise that Le Corbusier provides colors a posteriori in buildings, as some different critics remark ${ }^{24}$, Purism considers the idea of form precedes color: "form is prominent, and color is only one of its accessories. Color entirely depends on the material form: the concept sphere, for instance, precedes the concept color. A colorless sphere is conceived, a colorless plane, no color is conceived independent of any medium" 25 . The Purism, like Cubism, first interests on shapes, while other artistic movements, such as Expressionism and Fauvism, prioritize color. V. Kandinsky (18661944) discuss about that, concerning the work of Picasso, in relation to Matisse: "If color disturbs to solve the problem of a purely pictorial shaping, he throws it away. (...) 
These are two great ways to reach a great goal, Matisse by color and Picasso by form" 26.

Whereas Le Corbusier first prioritizes the volumes of architecture and their play with the light, Taut first considers light itself (color) and next form. The architect should "shape the appearance of light". Quoting Hans Poelzig (1869-1936), Taut says "the color is the starting point of a new style before form is refined" 27.

Either a priori or a posteriori addition, the fact is that modern architects seem to be faithful to the following principle: the color always extends up to a full architectural element, and does not change its hue, value or chroma. The principle of "flat colors" is shared both by Le Corbusier, Rietveld and Taut. Even Johnson and Hitchcock proposed it as a criterion for "modernity", considering that "it is important that the surface is flat, not concave or convex, since otherwise the effect would be colorful and the impression of multi-directional tensions would be lost" ${ }^{2}$.

To be more precise, it should be noted that sometimes there is a change in hues within a single architectural element, although it occurs abruptly, with no gradation. So, it can be seen that in the Aubette Café, Van Doesburg (1883-1931) provides different shades on the same surface, but these are always limited with a black line. The beginning and ending of color shapes are clearly shown: colors are clearly defined. Or color fits with the whole object or it builds its own borders.

However, the Italian architect Piero Bottoni claimed to use the gradation of colors instead of flat colors in his manifesto "Chromatismi Architettonici" (1927), while modern conceptions were still being discussed. This theoretical writing is accompanied with watercolors where the color of the buildings changes its brightness in the vertical edge and its hue in the horizontal one. Bottoni argues that the "volumetric function of color has never been studied enough and, moreover, the "mass-volume" power attributed by a color to a geometric solid plays an important role in the aesthetic balance and the perception of the "resistant" values of any structure" 28.

But it was clear that the gradation of color was out of the orthodoxy of "flatconstructive color" and opened the dangerous possibility of an unjustifiable color, that rather than conform, deform. In this sense it was inevitable for Bottoni to be criticized by some colleagues (including compatriots) like Alberto Sartoris, who actually evidences that "if you provide, as it did Bottoni, on a large wall, a color that approaches together with another that goes away, it is fully broken both volume and surface". And even more emphatically, asserts that "Bottoni has provided those colors that approach and distant, all along the facade, what should not be done. When Van Doesburg, however, cut a façade, he did so with those colors that approach or distant, but never mixed them together" ${ }^{29}$.

Alberto Sartoris can not be labelled to be suspicious of rejecting color, as many of his buildings are colored. Of course, he distance to any decorative conception and claims for a color consistent with other properties of shapes, not as a post added: "I have abolished the word decoration and replaced by the word incorporation. (...) The painters painted the wall at the end, when everything was finished, while the wall should be an integral part of architecture and should be thought first" ${ }^{30}$.

Alberto Neppi says about Bottoni's watercolors that "they might be interesting for scenography, but not for architecture worthy to be called as such" ${ }^{31}$. The young Italian architect strongly replied that his was a "truly architectural interpretation" of color guaranteed by Le Corbusier himself. Of course, it should be emphasized the intellectual audacity of Bottoni's proposal and the rigor to understand and interpret the color, although it achieved little influence on immediate architectural development. 
If there is an element in common for every architectural movements in modern period, it is the desire to promote a cultural change embedded in society, an ethical conception that transcends the various aesthetic assumptions and which is transferred to color composition. The Spanish philosopher J.A. Marina dares to state that "modern art was not art but a moral and libertarian preaching. That is its greatness, what made it be chased by Nazis or Soviet dictatorships" ${ }^{32}$.

This socio-cultural change reaffirmed itself by opposition to the proposals of the academic architecture of the XIX century. In relation to color, it causes two contradictory positions, as rightly points out Prof. Caivano, as the academicism is equally criticize "for its lack of color" by some architects, as well as "for using color" by others" 4 . Both the use of stark colors and full-color provisions share a common ethical background rejecting the past.

Several authors have noted that Le Corbusier theoretical interest in white color is better understood from an ideological point of view rather than a plastic one. Otherwise, it would have no sense that the Swiss master stated that "to be honest, my homes do not seem white until I provide active forces of color and values in appropriate places" 25. But Le Corbusier's interests are closer to cultural rather than social concerns. Being distant from the German Siedlungen, we do not find in his building complex in Pessac such social motivations. Le Corbusier said that it is the "use of an absolutely new polychromy, mainly rational" 13 (obra completa, p. 85).

However, Taut believes that bold color compositions, like his Glass Pavilion for the exhibition of the Deutscher Werkbund (Cologne, 1914) predict the arrival of a new era. This building summarizes the utopian ideals collected by P. Scheerbart (1863-1915) in Glass Architecture (1914), as well as the prophetic advent of a new culture advocated by the architect Adolf Behne (1885 to 1948). Taut believes that color is able to shed light on the shadows, what must be understood not only in a metaphorical sense but also in a plastic one, color is able to "illuminate" a new society and a new architecture. Color has moral and physical effects and is justified by observing the behaviour of children, who prefer to play in those streets with cheerful colors.

The artistic convictions of neoplasticists also lean on a spiritual or even mystical substrate, influenced by the writings of V. Kandinsky, who talks about the "inner eye" that "passes through the outer form, penetrating to the depths of things and allows us to perceive with all senses his intimate pulse" ${ }^{26}$. Still, neoplasticism has less committed social positions than other movements, as J.J.P. Oud (1890-1963) ensures: "From there it could not emerge a healthy, universal and comprehensive social architecture, that is to say, from such an abstract aesthetic. However, the Neoplasticism has given to us, with no doubt, architectural values that I would not like to lose. My situation is similar to that of ancient alchemists, who seeking gold, found no gold but another precious material" ${ }^{33}$.

In the late twenties, Van Doesburg said that "white is the color of the new age" 34 . So we can conclude that the neoplastic approach to color is not dogmatic, as both the primary colors and white have the ability to lead the arrival of the new culture. Curiously, and in a contradictory manner, in European countries ruled by totalitarian regimes during the thirties, polychromy was rejected as it was considered the expression of democracy ${ }^{35}$.

Regardless the range of shades used, the common ethical conscience of every movement to reject academism, leads them to avoid the use of color in a decorative 
way. They use several mechanisms: the imitation is left in favour of the "material truth", figuration is abandoned in favour of abstraction and, in general, color becomes intellectualized to prevent arbitrary or capricious rules.

Neoplasticists achieve so by robbing the color of "any emotional content, understanding it as an abstract matter that can be organized according to rational principles ${ }^{36}$. They believe that Cubism has not gone far enough in its abstraction and are suspicious about Expressionism for being too private ${ }^{37}$. The members of De Stijl are not interested in the representation of the sensual experience, or "the stimulating effect on the nerves" or the "concentrating effect" that Taut feels in his Glass Pavilion "38, but imagine the artist as a scientist in his laboratory, intellectually analyzing the form and color ${ }^{39}$. Neoplasticists aim to reach a more universal and ethical culture: "In the future, thefulfillment of pure figurative expression in the tangible reality of our environment will replace the work of art, but to achieve this it is required to shift it towards a universal representation and a separation from the pressure of nature" ${ }^{40}$. This separation from nature is achieved by reducing architecture to what it is essential: the plane or line in regard to shapes, and basic hues in regard to color. That is, those colors that are at the root of any others, that Neoplatonic philosopher M. J. H. Schoenmaekers (1875-1944) endowed with a metaphysical sense: "Yellow is the movement of the beam (the vertical). (...) Blue is the color that contrasts with yellow (the horizontal sky). (...) Red is the coupling of yellow and blue" ${ }^{41}$.

Purism leaves decoration by looking for invariant and universal rules: "The work should not be accidental, exceptional, impressionist, inorganic or picturesque, but instead, general, static and expressive of what is invariable" ${ }^{42}$. So Purism suggests an "ultra-rationalist" theory which aspires to intellectually dominate color and reach a formal clearance. Although Le Corbusier and Ozenfant believe that color is a hazardous component in the expression of volume, as it is often destructive or disruptive, its effects can be known and directed ${ }^{13}$. Indeed, Le Corbusier sometimes provides color to scatter an architectural shape from another and both to be perceived as autonomous objects, but rarely to reduce the volume itself to its component elements (lines and planes), something usual in Neoplasticism. Paradoxically, the rupture of a volume by using color in Le Corbusier's buildings, serves for a better understanding of the volume itself, which gets free of those secondary additions, as it has been noted with regard to the Ville Saboie. Le Corbusier said that color can put into order, prioritize or unify the final space ${ }^{13}$, referring to the Salubra color system. His attempt to rationalize and control the chromatic variables, is comparable to the system of proportions of The Modulor (1948 and 1953), although this was never used in such a dogmatic way in architecture as he did with respect to the metric system.

Bruno Taut also evolved from initial expressive provisions in the beginning to functional color provisions in last period. With regard to his own house in BerlinDahlewitz (1927), he says that "what it is purely aesthetic... here it is just the consequence of the practical" 39 . The architect ends up rationalizing the color composition, brandishing functional arguments to support his formal decisions.

\section{Conclusions}

When investigating three of the most relevant color compositional systems during the first half of the $20^{\text {th }}$ century (Purism and Le Corbusier, Expressionism and B. Taut, Neoplasticism and TG Rietveld), three non categorical principles have been 


\section{References}

1 Serra J. Colores que alumbran proyectos. Conversando con William Alsop. EGA. Revista De Expresión Gráfica Arquitectónica; 2009. p. 16-25.

2 Hitchcock H, Johnson PC, Colegio Oficial de Aparejadores y Arquitectos Técnicos de Murcia. El estilo internacional: Arquitectura desde 1922. Murcia: Colegio Oficial de Aparejadores y Arquitectos Técnicos; 1984.57 p. 68, 94.

3 Ramírez JA. Arte y arquitectura en la época del capitalismo triunfante. Madrid: Visor Libros; 1992. p. 258

4 Pelli C. In Caivano JL. Research on color in architecture and environmental design: Brief history, current developments, and possible future. Color Res Appl 31(4):350-63.

5 De las Casas M. 1991. In Táboas Veleiro T. 1991. El color en arquitectura. A Coruña: Edicios do Castro; 2006. p. 191

6 Meier Richard. Ceremoni accepetance speech of the pritzker prize. ; 1984; National Gallery of Art in Washington D.C. 1984.

7 Le Corbusier. Hacia una arquitectura. 2a ed. Barcelona: Apóstrofe; 1998. p. 243

8 Wigley M. White walls, designer dresses : The fashioning of modern architecture. Cambridge: MIT Press; 1995. p. 424

9 Serra Juan. The myth of white color in modern architecture. Conference in I seminário internacional cor arquitectura e design. Universidade Lusiada Lisboa: 30th October 2009.

10 Cramer N. It was never white, anyway. Architecture; 1999. p. 88 (2).

11 Montaner JM. Arquitectura y crítica. Barcelona: Gustavo Gili; 1999. p.109

12 Batchelor D. Chromophobia. London: Reaktion Books; 2000. p.124 
13 Le Corbusier and Rüegg A. Polychromie architecturale : Le corbusier farbenklaviaturen von 1931 aund 1950=Le corbusier's color keyboards from 1931 and 1959=Les claviers de couleurs de le corbusier de 1931 et de 1959. Basel: Birkhäuser; 1997. p. 95, 113.

14 Taut B. 1925. In Duettmann M, Schmuck F, Uhl J. El color en la arquitectura. Barcelona: Gustavo Gili ; 1982. p. 191.

14b Schumacher, F. 1901. Der Kunstwart, vol. 20. In Duettmann M, Schmuck F, Uhl J. El color en la arquitectura. Barcelona: Gustavo Gili; 1982. p. 191

15 Colegio Oficial de Arquitectos de Madrid and Fundación Cultural COAM. Cuatro siedlungen berlinesas de la república de weimar: Britz, Onkel Toms-Hütte, Siemensstadt. Weise Stadt [exhibition]. Madrid: Colegio Oficial de Arquitectos de Madrid, Argon; 1992 p. 237

16 Taut B. 1925. In: El color en arquitectura. Táboas Veleiro, Teresa. A Coruña: Edicios do Castro, 1991. $177 \mathrm{p}$.

17 Besset M. La couleur et l'architecture dans les annees 1920. Ecole Polytechnique Federale De Lausanne, DA-Informations 144; 1993.

18 Mondrian P. 1930. "La morfología y la neoplástica" en circulo y cuadrado, num. 2. González García A, Calvo Serraller F,Marchán Fiz S, editors. In: Escritos de arte de vanguardia 1900/1945. Madrid (España): Istmo. $270 \mathrm{p}$.

19 Der Leck B. El lugar de la pintura moderna en la arquitectura. In de stijl, 1918, vol. I, num. 1, p. 2-6. in González García A, Calvo Serraller F,Marchán Fiz S, editors. Escritos del arte de vanguardia 1900/1945. Madrid (España): Istmo. 256 p.

20 Schindler VM. Colour culture in European architecture and Le Corbusier: On different approaches to applying colour in architecture; Proceedings of the AIC Congress, 2004. p. 393-401.

21 Léger F. 1952. Nuevas concepciones del espacio. In: Funciones de la pintura. Barcelona (España): $1990.95 \mathrm{p}$.

22 Le Corbusier. 1962. Modulor 2 : 1955 (los usuarios tienen la palabra) continuación de "El Modulor" "1984". Buenos Aires: Poseidón. 335 p. -239

23 Martina Colli L. Hacia una policromía arquitectónica. In: Le corbusier, une encyclopédie. Paris, exhibition "L'aventure Le Corbusier" in Galeria del Centro Nacional de Arte y Cultura George Pompidou: Centre de Crêation Industrielle ; 1987. p. 97

24 Carro R. Le Corbusier nos hizo el regalo del muro blanco. VIA Arquitectura; 2003.

25 Ozenfant A, Le Corbusier. 1920. Purismo. In: Acerca del Purismo: Escritos 1918-1926. Madrid: El Croquis, 1994. $297 \mathrm{p}$.

26 Kandinsky V. 1922. De lo espiritual en el arte. $3^{\mathrm{a}}$ ed. Barcelona: Labor; 1992. p.122

27 Taut B. 1925. Renacimiento del color. Extract from "Farbe am hause", 1er German Color Congress, Hamburg, Berlin. "bauweltverlag, 1925". In: AA. VV. color en la arquitectura (farbe im stadtbild). Barcelona: Gustavo Gili. 191 p.

28 Bottoni P. Cromatismi architettonici. Architettura e Artti Decorative; 1927. VI(1-2).

29 Sartoris A. 1993. Interview with Sartoris. Mantegna, Caterina. Tesis De Laurea: Il Colore Della Cultura Architettonica Delle Avanguardie Storiche Del Novecento / (1). Unpublished.

30 Sartoris A. 1993. Interview. Cristina Rivadossi; Rel. Gabriella Zuco; Co-Rel. Silvia Portaluppi, Carlo Arduino. L' Integrazione Delle Arti Ed Il Colore Nel Pensiero e Nell'Opera Di Alberto Sartoris. Milano : Politecnico. - 349 p. ; 31 cm. (Tesi datt. - Politecnico di Milano, Architettura, Laurea in Architettura, A.a. 1993/94. Unpublished.

31 Bottoni P. Polemiche per l'architettura. Il Raduno; 1928. p. 2

32 Marina JA. El misterio de la voluntad perdida. $5^{\mathrm{a}}$ ed. Barcelona: Anagrama;1998. 324 p. 213

33 Benevolo L. Historia de la arquitectura moderna. 2a $6^{\text {a }}$ ed. Barcelona: Gustavo Gili, 1974. p. 944

34 Doesburg TV. The will of style. Form and Function: 1922.

35 Noury L. La couleur dans la ville. Thouard V, editor. 1st ed. Paris: Moniteur (Départment Architecture); 2008. p. 168.

36 Ramírez Luque I. Mucho más que una cuestión de piel. la experiencia del color en la arquitectura contemporánea. Romero de Solís D, Murcia Serrano I,López Lloret J, editors. In: Variaciones sobre el color. Sevilla: Universidad de Sevilla; 2007. 371 p.: 354

37 Dempsey A. Estilos, escuelas y movimientos: Guía enciclopédica del arte moderno. Barcelona: Blume; 002. p. 304.

38 Taut B. 1919. Beobachtungen ubre farbenwinkürgen aus meiner praxis. Die Wauelt, 39, p. 13. In: Color en la arquitectura. Barcelona: Gustavo Gili, 1982. p. 191.

39 Taut B. 1927. In Pehnt W. La arquitectura expresionista. Barcelona et alt.: Gustavo Gili: 1975. p.235

40 Mondrian P. Arte plastico y arte plastico puro. 2a. ed. Buenos Aires: Victor Leru; 1961. p. 96

41 Schoenmaekers. 1915. Het Niewe Wereldbeeld. In: Frampton K. Historia critica de la arquitectura moderna. $1^{\text {a }}, 5^{\mathrm{a}}$ ed. Barcelona: Gustavo Gili; 1981.p. 338. 
1

2

3

4

5

6

7

8

9

10

11

12

13

42 Le Corbusier and Ozenfant A. 1918. El purismo. Calvo Serraller F, González García Á,Marchán Fiz S, editors. In: Escritos de arte de vanguardia : 1900-1945. Madrid: Istmo. p. 84

\section{Figures:}

1 Taut B. and Nerdinger W. 2001. Bruno Taut : 1880-1938. Milano: Electa. 435 p.

2 Ibid Taut B. and Nerdinger W. 2001.

3 Ibid Taut B. and Nerdinger W. 2001.

4 Lucan J. and Le Corbusier. 1987. Une Encyclopédie. Paris : Centre Georges Pompidou. Exhibition 'L' aventure Le Corbusier “, October 1987-January 1988, Centre National d' Art et de Culture Georges Pompidou, Paris.

5 Ibid Lucan J. and Le Corbusier. 1987

6 Ibid Taut B. and Nerdinger W. 2001.

7 Rietveld G. and Román A. 1996. Gerrit Th. Rietveld, 1888-1964. Madrid: Ministerio de Obras públicas, Transportes y Medio Ambiente. pp. 40.

8 Ibid Lucan J. and Le Corbusier. 1987

9 In http://www.joostdevree.nl/

$10 \mathrm{Ibid}$ Lucan J. and Le Corbusier. 1987

11 In http://www.flickr.com/photos/yisris/267935008/

12 Ibid Lucan J. and Le Corbusier. 1987 


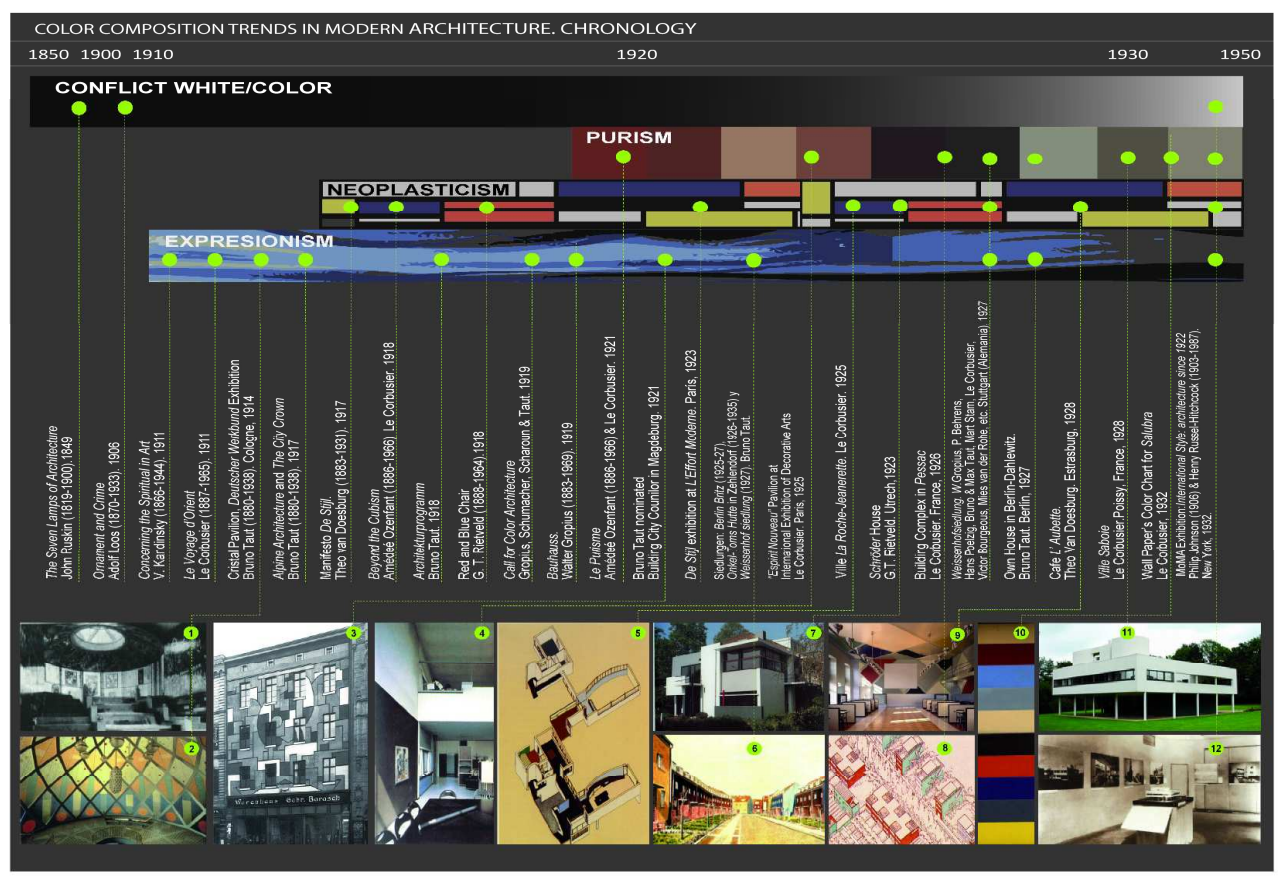

COLOR COMPOSITION TRENDS IN MODERN ARCHITECTURE. CHRONOLOGY $285 \times 197 \mathrm{~mm}(300 \times 300 \mathrm{DPI})$ 